\title{
Animal age and sex effects on diets of grazing cattle
}

\author{
E.E. GRINGS, R.E. SHORT, M.R. HAFERKAMP, AND R.K. HEITSCHMIDT
}

Authors are research animal scientist, research physiologist, rangeland scientist, and supervisory rangeland scientist, USDA, Agricultural Research Service, Fort Keogh Livestock and Range Research Laboratory, Miles City, Mont. 59301.

Abstract

The effects of animal age and sex on chemical and botanical composition of diets of cattle grazing native rangelands were evaluated in a 2-year study. Samples were collected monthly from June through October using esophageally cannulated suckling calves, yearling heifers, mature cows, and mature steers. Dietary crude protein and digestibility differed among animal classes, but these differences varied over time. These 2 diet quality indicators did not vary in the same manner over time for all animal classes. Dietary crude protein varied from a low of $7.2 \%$ for steers in August 1994 to a high of $\mathbf{1 4 . 3 \%}$ for heifers in June 1993. In vitro digestibility varied from a low of $\mathbf{5 0 . 7 \%}$ for cows in October 1993 to a high of $74.3 \%$ for calves in June 1993. Botanical composition of diets varied with animal class and sampling date with interactions among these. Cool-season grasses accounted for an average of $70 \%$ of the diet with a range of 33 to $90 \%$. Shrubs varied from 1 to $61 \%$ of the diet. Differences in chemical composition among age and sex classes of cattle grazing native rangeland during the growing season may be partially related to differences in botanical composition of diets. Animals used to obtain diet samples should, therefore, be of similar physiological state and age as animals being monitored for performance.

Key Words: diet selection, beef cattle, calf, steer, heifer

Esophageal diet sampling is one technique used to obtain diet quality information needed to estimate digestibility and intake of grazing cattle. Researchers often use a single class of animals to determine diet quality for all animals. For example, some researchers have used mature steers for sampling because of their ease of handling. These steers may differ in physical stature, body composition, intake as a proportion of body weight, and nutrient requirements compared with the cattle being monitored for performance. A number of researchers have observed differ-

The authors express appreciation to Byron Hould, Richard Bonine, and Brooke Shipp for assistance in sample collection, Susan Reil for sample collection and laboratory analysis, Mary Ellen French for assistance with graphics, and Dr. Michael MacNeil for assistance with statistical analysis.

This paper is a contribution from the U. S. Department of Agriculture, Agricultural Research Service and the Montana Agricultural Experiment Station, Miles City, Mont.

U. S. Department of Agriculture, Agricultural Research Service, Northern Plains Area, is an equal opportunity/affirmative action employer, and all agency services are available without discrimination.

Mention of a proprietary product does not constitute a guarantee or warranty of the product by USDA, Montana Agri. Exp. Sta., or the authors and does not imply its approval to the exclusion of other products that may also be suitable.

Manuscript accepted 25 Apr. 2000.

\section{Resumen}

En un estudio de dos años se evaluó el efecto de la edad y sexo del animal en la composición botánica y química de la dieta del ganado apacentando pastizales nativos. Las muestras se colectaron mensualmente de Junio a Octubre utilizando becerros sin destetar, vaquillas, vacas maduras y novillos con cánulas esofágicas. La proteína cruda dietaria y la digestibilidad difirieron entre las clases de animal y estas diferencias variaron a través del tiempo. Estos dos indicadores de la calidad de la dieta no cambiaron de la misma manera a través del tiempo para todas las clases de animal. La variación de la proteína cruda dietaria fue de $7.2 \%$ en la dieta de los novillos en agosto de 1994 a $14.3 \%$ en la dieta de las vaquillas en Junio de 1993. La digestibilidad in vitro vario de de $\mathbf{5 0 . 7 \%}$ en la dieta de las vacas en Octubre de 1993 a $74.3 \%$ en la dieta de los becerros en Junio de 1993. La composición botánica de la dieta vario con la clase de animal y la fecha de muestreo con interacciones entre estos factores. Los zacates de estación fría aportaron aproximadamente el $70 \%$ de la dieta y el rango de ellos fue del 33 al $90 \%$, los arbustos variaron del 1 al $6 \%$ de la dieta. Las diferencias en la composición química de la dieta entre edad y sexo del animal del ganado apacentando pastizales nativos durante la estación de crecimiento puede estar parcialmente relacionada a las diferencias en la composición botánica de las dietas. Los animales utilizados para obtener las muestras de las dietas deben estar en el mismo estado fisiológico y edad que los animales que están siendo monitoreados para determinar su comportamiento productivo.

ences in diet selection between young, suckling ruminants and older animals (Horn et al. 1979, Ferrar Cazcarra and Petit 1995, Grings et al. 1995). Langlands (1969) found differences in diet selection due to animal age, but not sex. Mohammad et al. (1996) found limited diet compositional differences between mature cows and 2-year-old steers on semidesert range. The greatest differences occurred during fall and these authors suggested differences in diet selection between sexes may be more apparent during periods of limited forage availability. The effects of animal class (age or sex) on diet selection may be dependent on the quality as well as quantity of available herbage. Wallace et al. (1972) suggested the lack of difference between quality of available forage and selected diets of cattle on eastern Colorado rangeland during winter was due to the uniform chemical composition of forages available. The objective of this study was to evaluate the influence of animal age and sex on botanical and chemical composition of diets obtained by cattle grazing Northern Great Plains rangeland. 


\section{Material and Methods}

The study was conducted at the Fort Keogh Livestock and Range Research Laboratory near Miles City, Montana ( $46^{\circ}$ $22^{\prime} \mathrm{N} 105^{\circ} 5^{\prime} \mathrm{W}$ ). Climate is continental and semi-arid with vegetation dominated by western wheatgrass [Pascopyrum smithii (Rydb.) Love]), threadleaf sedge [Carex filifolia Nutt.], needle and thread [Stipa comata Trin. and Rupr.], blue grama [Bouteloua gracilis (H.B.K.)], and downy [Bromus tectorum L.] and Japanese bromes [B. japonicus Thunb.]. Average annual rainfall in the area is $338 \mathrm{~mm}$ with $60 \%$ received during the 150 -day, midApril to mid-September growing season (Fig. 1)

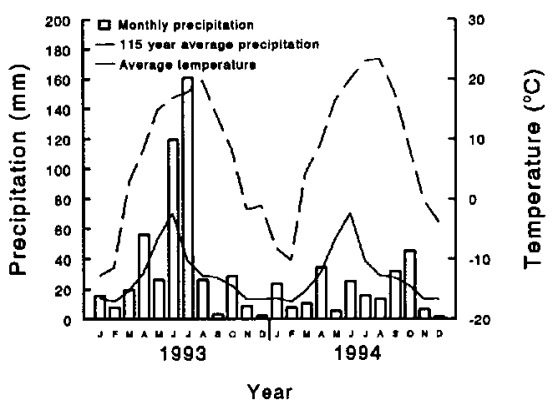

Fig. 1. Average precipitation (bars) during the study years of 1993 and 1994 compared to a 115-year average (solid line) and average monthly temperature (dashed line) during the study years.

The study utilized esophageally cannulated suckling heifer calves, yearling heifers, mature cows, and mature steers. Six mature steers (5- to 6-years old) and 6 lactating cows (2- to 5-years old) were used. All but 1 cow were used both years. Weight, body condition, and physical stature of cows was different than steers. Calves were 4 months old at the first sample collection period after having been cannulated at 2 months of age. During 1993, 6 yearling heifers and 6 heifer calves were used, while during 1994, 4 yearling heifers and 8 heifer calves were used. Yearling heifers used during 1994 were the calves used during 1993. Steers and cows had considerable experience in the pastures during earlier winters and were familiar with the vegetation and topography. Heifers had previously grazed pastures with similar range sites and were experienced with the forage species available. Calves had grazing experience but not with all forage species available.
Samples were collected each month from June through October of 1993 and 1994 in 2 vegetatively similar native rangeland pastures of 85 and 90 ha. These pastures were grazed with yearling steers at a density of 4.4 ha steer ${ }^{-1}$ from mid-May to mid-September 1993 and from midMay to late August 1994.

Cattle used for diet sampling were brought to the site the day before sampling and were held overnight without feed but with water available. Collection bags were placed on cattle at 0700 hours and they were allowed to graze the first pasture for 30 to $45 \mathrm{~min}$. These procedures were repeated a second day in the second pasture. Due to problems with sample collections, not all animals collected a sample for each month. Except for yearling heifers, samples from the 2 days were composited by weight, frozen, lypholyzed, and ground to pass a 1-mm mesh screen in a Wiley mill. Samples for yearling heifers for all months except October were being used to evaluate diet quality for a concurrent study that required analysis by individual pasture. Therefore, analyses were conducted on individual samples and averaged over 2 days.

Samples were divided with one-half used for analysis of crude protein (Hach 1987) and in vitro organic matter digestibility (Tilley and Terry 1963) without supplemental nitrogen and the other half used for microhistological analysis for botanical composition (Sparks and Malechek 1968). One slide of each sample was read (20 fields) for microhistological analysis at a commercial laboratory (Composition Analysis Laboratory, Fort Collins, Colo)

Forage availability on 2 representative range sites was determined during the same week that diet samples were collected. The sites were clay pan and silty-shallow and represented 15 and $49 \%$, respectively, of the pasture area. Standing crops were visually estimated by giving a score of 1 (high) to 4 (low) in 20 randomly placed $0.25 \mathrm{~m}^{2}$ quadrats within each of 2 range sites. Every fifth plot was clipped to ground level, dried, and weighed. Linear regression was used to estimate standing crops from vegetation abundance scores. Separate regressions were used for each range site and month. Additional pastures were evaluated at the same time so that 16 clipped plots were used for each regression. Botanical composition of each plot was estimated by the dry weight rank method (t'Mannetje and Haydock 1963). Forage samples were composited by range site, ground to pass a 1 $\mathrm{mm}$ mesh screen in a Wiley mill and ana- lyzed for crude protein and in vitro organic matter digestibility.

Data were analyzed using the General Linear Models Procedures of SAS (1989). Error mean squares were generated from a model containing animal class, month, year, and all associated interactions, and individual animal within animal class. This last component was used to test the effect of animal class on diet selection. Because animal class changed between years (i.e., 1993 calves became 1994 yearling heifers), the term for individual animal within animal class was deleted and the model rerun to produce estimable least squares means. Standard errors of the least square means were then corrected using the error mean square from the initial model. Mean separation was by least significant difference if a significant F-test was observed.

\section{Results and Discussion}

Botanical composition of the pastures was dominated by cool-season grasses with some warm-season grasses, annual grasses, sedges, and forbs present (Table 1). Shrub biomass was not estimated.

Table 1. Average botanical composition of available herbage on 2 representative range sites within the pastures sampled for diet quality. Shrubs were not included in the estimates.

\begin{tabular}{lcc}
\hline \hline & 1993 & 1994 \\
\hline & $---(\%$ of biomass $)---$ \\
Cool-season grasses & 54 & 61 \\
Warm-season grasses & 17 & 21 \\
Annual grasses & 3 & 1 \\
Carex spp. & 6 & 5 \\
Forbs & 20 & 12 \\
\hline
\end{tabular}

Forage availability ranged from 1,129 to $2,047 \mathrm{~kg} \mathrm{ha}^{-1}$ on 2 sites within the pastures (Table 2). Precipitation between the 2 years differed (Fig. 1) with resulting differences in available forage and herbage quality (Table 3 and 4).

Seasonal diet quality trends were observed for all animal classes, but dietary crude protein exhibited various interactions among animal class, month, and year $(\mathrm{P}<0.10$; Table 3$)$. The only animal class -month combinations not differing in dietary crude protein between years were diets of calves, heifers, and cows in June and heifers in July.

Diets of calves and heifers generally had greater crude protein concentrations than 
Table 2. Herbage mass of 2 range sites within pastures sampled by esophageally cannulated cattle on 5 dates in 2 years. Standard error of the mean $=26.8, n=20$.

\begin{tabular}{|c|c|c|c|c|c|}
\hline & June & July & Aug & Sep & Oct \\
\hline 1993 & & & $\left.\mathrm{ha}^{-1}\right)-$ & & ---"- \\
\hline Clay pan & 2047 & 1762 & 1799 & 1754 & 1737 \\
\hline Silty-shallow & 1426 & 1555 & 1590 & 1344 & 1363 \\
\hline \multicolumn{6}{|l|}{1994} \\
\hline Clay pan & 1957 & 1967 & 1879 & 1803 & 1129 \\
\hline Silty-shallow & 1507 & 2008 & 1490 & 1275 & 1393 \\
\hline
\end{tabular}

Table 3. Least square means of dietary crude protein and during 2 growing seasons for 4 classes of cattle. Pooled standard error of the mean for diet crude protein $=0.08$.

\begin{tabular}{|c|c|c|c|c|c|}
\hline & June & July & Aug & Sep & Oct \\
\hline 1993 & \multicolumn{5}{|c|}{ (\% of organic matter)-- } \\
\hline Calves & $14.2^{\mathrm{a} 1}$ & $12.6^{\mathrm{a}}$ & $10.9^{\mathrm{a}}$ & $10.8^{\mathrm{a}}$ & 8.9 \\
\hline Heifers & $13.5^{\mathrm{a}}$ & $11.7^{\mathrm{ab}}$ & $10.8^{\mathrm{a}}$ & $9.1^{\mathrm{b}}$ & 8.9 \\
\hline Cows & $11.8^{\mathrm{b}}$ & $11.2^{\mathrm{b}}$ & $9.9^{\mathrm{a}}$ & $8.8^{\mathrm{b}}$ & 8.7 \\
\hline Steers & $9.8^{c}$ & $9.8^{\mathrm{c}}$ & $8.3^{\mathrm{b}}$ & $7.8^{\mathrm{c}}$ & 8.5 \\
\hline Herbage & 9.2 & 11.5 & 10.0 & 9.0 & 8.6 \\
\hline \multicolumn{6}{|l|}{1994} \\
\hline Calves & $14.2^{\mathrm{a}}$ & $10.9^{\mathrm{a}}$ & $8.5^{\mathrm{a}}$ & $7.7^{\mathrm{a}}$ & $12.7^{\mathrm{a}}$ \\
\hline Heifers & $14.3^{\mathrm{a}}$ & $11.0^{\mathrm{a}}$ & $9.0^{\mathrm{a}}$ & $7.6^{\mathrm{a}}$ & $12.3^{\mathrm{ab}}$ \\
\hline Cows & $11.7^{\mathrm{b}}$ & $8.2^{\mathrm{b}}$ & $7.3^{\mathrm{b}}$ & $7.5^{\mathrm{a}}$ & $13.2^{\mathrm{bc}}$ \\
\hline Steers & $11.1^{\mathrm{b}}$ & $8.2^{\mathrm{b}}$ & $7.2^{\mathrm{b}}$ & $9.6^{\mathrm{b}}$ & $13.6^{\mathrm{c}}$ \\
\hline Herbage & 8.5 & 9.0 & 6.3 & 8.3 & 8.4 \\
\hline
\end{tabular}

${ }^{\mathrm{M}}$ Means within month by year with different superscripts differ by animal class $(\mathrm{P}<0.05)$.

Significant effects in the model were animal class, $\mathrm{P}<0.01$; month, $\mathrm{P}<0.01$; animal class $\mathrm{x}$ month, $\mathrm{P}<0.01$; animal class $\mathrm{x}$ year, $\mathrm{P}<0.01$; month $\mathrm{x}$ year, $\mathrm{P}<0.01$, individual animal within animal class, $\mathrm{P}<0.01$, animal class $\mathrm{x}$ month $\mathrm{x}$ year, $\mathrm{P}<0.10$.

other animal classes, but differences decreased as the season progressed. During 1993, steer diets contained less crude protein than diets of other animal classes except at the October sampling, when there were no differences due to animal class. During 1994, crude protein concentrations of steer diets did not differ from those of cows except in September, when diets of steers had greater crude protein concentrations than any other animal class.

There were fewer differences among animal classes for in vitro organic matter digestibility (Table 4) than for crude protein. Digestibility did not differ $(\mathrm{P}>0.10)$ among animal classes for the August 1993, July 1994, and October 1994 samples. Heifer diets were often lower in digestibility than calf diets, even when they did not differ in crude protein.

While general trends in diet quality throughout a growing season may be similar among animal classes, absolute values may be different. Animal class by month interactions for both crude protein and in vitro organic matter digestibility indicate that prediction of the diet quality of one class from another is not advised.

The differences in dietary selection between steers and cows may be related to more than gender. Physiological states and 0.18.
Baker 1981). Ferrar Cazcarra and Petit (1995) reported that 7-month-old calves had higher fecal nitrogen than both 18month-old heifers and adult cows. This occurred irrespective of sward height in pastures of orchardgrass (Dactylis glomeratus L.). These researchers suggested that calves ate smaller, shallower bites resulting in a diet consisting of more leaf with higher protein content than heifers or cows.

The choice of animal class to use for studies intended to rank varieties or forage treatments may be of limited concern, but it is critical to use the appropriate animal class when nutrient intake and digestion are being considered. For example, if mature steers had been used to estimate diet quality for yearlings during June 1993, crude protein would have been underestimated by 4 percentage units (9.8 vs $13.5 \%$, Table 3 ) compared to using yearlings to collect diet samples. The subsequent error in nutrient intake and digestibility would be quite large. The heifers in this study were being used to estimate diet quality for steers grazing these pastures during this time period. Using heifer diet quality values resulted in crude protein intakes of $737 \mathrm{~g} \mathrm{day}^{-1}$ for yearling steers. If we had used diet quality as collected by mature steers, our crude protein intake estimates would have been only $521 \mathrm{~g} \mathrm{day}^{-1}$. We might have suggested differing management strategies for these cattle based upon our erroneous results.

Crude protein levels of available forage were below that of all selected diets during June and October of 1994, indicating strong diet selection at these times (Table 3 ). Relationship of diet crude protein to forage crude protein during other months differed. In vitro organic matter digestibility of available forage was always well below that of diets (Table 4).

Table 4. Least square means of in vitro organic matter digestibility during 2 growing seasons for 4 classes of cattle. Pooled standard error of the mean for diet in vitro organic matter digestibility =

\begin{tabular}{|c|c|c|c|c|c|}
\hline & June & July & Aug & Sep & Oct \\
\hline 1993 & ---------- & ----(9) & ic matt & -- & ------- \\
\hline Calves & $74.3^{\mathrm{a} 1}$ & $68.3^{\mathrm{a}}$ & 62.5 & $61.9^{\mathrm{a}}$ & $54.7^{\mathrm{a}}$ \\
\hline Heifers & $66.5^{\mathrm{b}}$ & $62.5^{\mathrm{b}}$ & 59.8 & $58.6^{\mathrm{b}}$ & $56.6^{\mathrm{ab}}$ \\
\hline Cows & $72.7^{\mathrm{a}}$ & $65.0^{\mathrm{bc}}$ & 62.4 & $58.6^{\mathrm{b}}$ & $50.7^{\mathrm{c}}$ \\
\hline Steers & $69.3^{\mathrm{b}}$ & $67.9^{\mathrm{ac}}$ & 60.9 & $58.5^{\mathrm{b}}$ & $58.6^{\mathrm{b}}$ \\
\hline Herbage & 52.4 & 52.6 & 49.3 & 49.5 & 46.9 \\
\hline \multicolumn{6}{|l|}{1994} \\
\hline Calves & $68.5^{\mathrm{a}}$ & 61.2 & $58.7^{\mathrm{a}}$ & $60.6^{\mathrm{a}}$ & 62.1 \\
\hline Heifers & $65.9^{\mathrm{a}}$ & 57.8 & $55.3^{\mathrm{b}}$ & $56.2^{\mathrm{b}}$ & 62.4 \\
\hline Cows & $67.1^{\mathrm{a}}$ & 59.7 & $57.7^{\mathrm{ab}}$ & $58.7^{\mathrm{ab}}$ & 63.6 \\
\hline Steers & $64.4^{\mathrm{a}}$ & 61.1 & $56.4^{\mathrm{ab}}$ & $58.1^{\mathrm{ab}}$ & 63.9 \\
\hline Herbage & 52.5 & 51.4 & 47.5 & 51.3 & 50.2 \\
\hline
\end{tabular}

${ }^{1}$ Means within month by year with different superscripts differ by animal class $(\mathrm{P}<0.05)$.

Significant effects in the model were animal class, $\mathrm{P}<0.01$; month, $\mathrm{P}<0.01$; animal class $\mathrm{x}$ month, $\mathrm{P}<0.01$; animal class $\mathrm{x}$ year, $\mathrm{P}<0.10$; month $\mathrm{x}$ year, $\mathrm{P}<0.01$; animal class $\mathrm{x}$ month $\mathrm{x}$ year, $\mathrm{P}<0.05$; individual animal within animal class, $\mathrm{P}<0.01$ 
Table 5. Least squares means of botanical composition of diets of cattle of 4 animal classes and total standing crop, June- October, 1993 and 1994.

\begin{tabular}{|c|c|c|c|c|c|c|c|c|c|c|c|c|}
\hline & \multicolumn{5}{|c|}{1993} & \multicolumn{5}{|c|}{1994} & \multirow[b]{2}{*}{ Mean } & \multirow[b]{2}{*}{ SEM } \\
\hline & June & July & Aug & Sep & $\overline{\text { Oct }}$ & June & July & Aug & Sep & Oct & & \\
\hline \multicolumn{13}{|l|}{ Number of samples in mean } \\
\hline Calves & 5 & 6 & 6 & 6 & 6 & 2 & 7 & 8 & 8 & 8 & & \\
\hline Heifers & 5 & 5 & 5 & 5 & 5 & 4 & 4 & 4 & 4 & 3 & & \\
\hline Cows & 6 & 6 & 6 & 6 & 6 & 6 & 6 & 6 & 6 & 6 & & \\
\hline Steers & 6 & 5 & 6 & 6 & 5 & 6 & 6 & 6 & 6 & 6 & & \\
\hline \multicolumn{13}{|l|}{ Cool-season grasses $(a b c d)^{1}$} \\
\hline Calves & 45 & 74 & 96 & 73 & 61 & 69 & 70 & 67 & 78 & 86 & 72 & 1.1 \\
\hline Heifers & 67 & 43 & 74 & 69 & 60 & 76 & 56 & 76 & 79 & 88 & 69 & \\
\hline Cows & 50 & 70 & 90 & 84 & 58 & 67 & 62 & 82 & 68 & 88 & 72 & \\
\hline Steers & 44 & 79 & 90 & 91 & 33 & 69 & 56 & 83 & 35 & 79 & 66 & \\
\hline \multicolumn{13}{|l|}{ Warm-season grasses $(c d e)$} \\
\hline Calves & 0 & 2 & 1 & 2 & 6 & 3 & 3 & 6 & 4 & 1 & 3 & .2 \\
\hline Heifers & 2 & 8 & 11 & 10 & 6 & 4 & 4 & 3 & 5 & 2 & 5 & \\
\hline Cows & 0 & 1 & 1 & 5 & 1 & 3 & 1 & 4 & 1 & 1 & 2 & \\
\hline Steers & 1 & 0 & 5 & 3 & 2 & 5 & 2 & 7 & 0 & 1 & 2 & \\
\hline \multicolumn{13}{|l|}{ Annual grasses (ace) } \\
\hline Calves & 2 & 1 & 0 & 2 & 6 & 0 & 1 & 1 & 1 & 3 & 1 & .1 \\
\hline Heifers & 2 & 1 & 0 & 10 & 6 & 3 & 2 & 3 & 3 & 4 & 2 & \\
\hline Cows & 2 & 2 & 1 & 5 & 1 & 4 & 1 & 0 & 0 & 5 & 2 & \\
\hline Steers & 2 & 1 & 0 & 3 & 2 & 0 & 1 & 0 & 0 & 2 & 1 & \\
\hline \multicolumn{13}{|l|}{ Sedges (acef) } \\
\hline Calves & 5 & 6 & 1 & 2 & 17 & 5 & 6 & 6 & 1 & 3 & 5 & 0.4 \\
\hline Heifers & 7 & 9 & 11 & 18 & 19 & 7 & 9 & 15 & 1 & 4 & 10 & \\
\hline Cows & 2 & 8 & 4 & 7 & 19 & 2 & 8 & 4 & 1 & 4 & 6 & \\
\hline Steers & 4 & 8 & 3 & 4 & 12 & 4 & 8 & 2 & 0 & 0 & 5 & \\
\hline \multicolumn{13}{|l|}{ Forbs $(a b)$} \\
\hline Calves & 3 & 1 & 1 & 1 & 0 & 6 & 2 & 0 & 0 & 1 & 1 & 0.1 \\
\hline Heifers & 1 & 1 & 0 & 1 & 1 & 2 & 1 & 0 & 1 & 0 & 1 & \\
\hline Cows & 2 & 1 & 0 & 1 & 0 & 1 & 0 & 1 & 0 & 1 & 1 & \\
\hline Steers & 0 & 2 & 0 & 1 & 0 & 3 & 0 & 0 & 4 & 0 & 1 & \\
\hline \multicolumn{13}{|l|}{ Shrubs $(a b c d e)$} \\
\hline Calves & 44 & 16 & 1 & 22 & 14 & 22 & 20 & 20 & 15 & 6 & 18 & 1.1 \\
\hline Heifers & 22 & 38 & 4 & 3 & 13 & 13 & 24 & 2 & 12 & 2 & 13 & \\
\hline Cows & 44 & 19 & 4 & 2 & 1 & 21 & 32 & 8 & 29 & 21 & 18 & \\
\hline Steers & 49 & 11 & 2 & 1 & 50 & 22 & 31 & 14 & 61 & 18 & 26 & \\
\hline
\end{tabular}

${ }^{1}$ Within botanical species there were significant effects of a month, $\mathrm{b}$ animal type $\mathrm{x}$ month, $\mathrm{c}$ month $\mathrm{x}$ year, $\mathrm{d}$ animal type $\mathrm{x}$ month $\mathrm{x}$ year, e animal type, and $\mathrm{f}$ year.

During mid-summer, diet quality did not always differ from available forage quality. This may have been influenced by the relative contributions of warm-season grasses. Warm-season grasses comprised about $18 \%$ of the standing crop on 2 common range sites within the study area. Diets of cattle contained only 1.8 (steers) to $6.8 \%$ (heifers) warm-season grasses during the months of July to September. Cattle were not selecting warm-season grasses even though they had the potential to increase dietary protein concentrations by doing so. In contrast, digestibility of diets was greater than the digestibility of available forage. Warm-season grasses may have lower digestibility than coolseason grasses (Haferkamp et al. 2001) and this may indicate why warm-season grasses were not highly preferred species.

Cool-season grasses accounted for an average of $70 \%$ of all diets (Table 5). Shrubs, averaging 19\%, were the next greatest component of the diet. Shrubs in the diet included winterfat (Ceratoides lanata (Pursh.) J.T. Howell), greasewood (Sarcobatus vermiculatus [Hook.] Emory.), shadscale (Atriplex confertifolia (Torr. and Frem.) Wats.), western snowberry (Symphoricarpos occidentalis Hook.), Wyoming big sagebrush (Artemisia tridentata Pursh. subsp. wyomingensis Beetle and Young), and fringed sagewort (Artemisia frigida Willd.). Forbs were a minor component of the standing crop and were, therefore, a minor component of the diet of this vegetation type.

Steer diets collected during September 1994 contained a large proportion of shrubs $(61 \%)$. This resulted in a crude protein concentration that was 2 percentage units above other animal classes. We observed some instances of either steers or older cows leading the herd to what appeared to be preferred sites within the pasture, often with a component of winterfat in the community. Winterfat accounted for 18 to $86 \%$ of the 6 steer diet samples collected during September 1994. Possibly, this degree of shrub consumption would not be maintained throughout an entire day of grazing. However, increased shrub consumption through even a portion of the day could have a significant influence on the chemical composition of the diet, such that diets of other animal classes would not be well represented by the diet collected from these steers.

Mohammed et al. (1996) found dietary overlap between cows and steers to vary with season with a range from 70 to $90 \%$. During spring and winter, cows consumed more grass and less forbs than steers. Although differences in shrub content in cow and steer diets differed at times, this difference was never greater than $4 \%$, much less than that observed during our study. Diet composition in the study of Mohammed et al. (1996) was determined from fecal samples and would represent a longer gazing period than our samples. 
We collected diet samples during a 30 to 45 min grazing bout on each of 2 mornings. Diurnal variation in diet selection may occur (Obioha et al. 1970, Van Dyne and Heady 1965), with potential compensation throughout the day for differences observed within the sampling period. However, it is common for researchers to use short-term grazing bouts to determine diet quality. Researchers utilizing fecal sampling to evaluate animal class comparisons (Langlands 1969, Mohammad et al. 1996) have also observed variation of diets among animal classes.

\section{Conclusions}

Alterations in botanical composition of diets of differing age and physiological classes of cattle can result in variations in chemical composition of those diets. Other factors are also involved in the variation in diet quality. Therefore, animals used to obtain diet samples on rangelands with diverse botanical composition should be of similar class as the animals being monitored for performance. This caution should be exhibited especially when forage availability is low, botanical diversity is high, and/or results are being used to estimate nutrient intakes.

\section{Literature Cited}

Ferrar Cazcarra, R. and M. Petit. 1995. The influence of animal age and sward height on the herbage intake and grazing behavior of Charolais cattle. Anim. Sci. (Pencaitland) 61:497-506.

Grings, E.E., D.C. Adams, and R.E. Short. 1995. Diet quality of suckling calves and mature steers on Northern Great Plains rangelands. J. Range Manage. 48:438-441.

Hach. 1987. Feed analysis manual. Hach Co., Ames, Iowa.

Haferkamp, M.R., R.K. Heitschmidt, E.E. Grings, M.D. MacNeil, and M.G. Karl. 2001. Suppression of annual bromes impacts rangeland: vegetation responses. J. Range Manage. 53 (In press).

Hodgson, J. and W.S. Jamieson. 1981. Variations in herbage mass and digestibility, and the grazing behaviour and herbage intake of adult cattle and weaned calves. Grass and Forage Sci. 36:39-48.

Horn, F.P., J.P. Telford, J.E. McCroskey, D.F. Stephans, J.V. Whiteman, and R. Totusek. 1979. Relationship of animal performance and dry matter intake to chemical constituents of grazed forage. J. Anim. Sci. 49:1051-1058.

Langlands, J.P. 1969. Studies on the nutritive value of the diet selected by grazing sheep. IV. Variation in the diet selected by sheep differing in age, breed, sex, strain and previous history. Anim. Prod. 11:369-378.
Le Du, Y.L.P. and R.D. Baker. 1981. The digestibility of herbage selected by oesophageally fistulated cows, steer calves, and wether sheep when strip-grazing together. Grass and Forage Sci. 36:237-239.

Mohammad, A.G., C.A. Ferrando, L.W. Murray, R.D. Pieper, and J.D. Wallace. 1996. Season and sex influences on botanical composition of cattle diets in southern New Mexico. J. Range Manage. 49:204-208.

Obioha, F.C., D.C. Clanton, L.R. Rittenhouse, and C.L. Streeter. 1970. Source of variation in chemical composition of forage ingested by esophageal fistulated cattle. J. Range Manage. 23:133-136.

SAS. 1989. SAS user's guide. Statistical Analysis System Institute, Inc., Cary, N.C.

Sparks, D.R. and J.C. Malechek. 1968. Estimating percentage dry weight in diets using a microscopic technique. J. Range Manage. 21:264-265.

Tilley, J.M.A. and R.A. Terry. 1963. A two stage technique for the in-vitro digestion of forage crops. J. Brit. Grassl. Soc. 18:104-111.

't Mannetje, L. and K.P. Haydock. 1963. The dry-weight-rank method for the botanical analysis of pasture. J. Brit. Grassl. Soc. 18:268-275.

Van Dyne, G.M. and H.F. Heady. 1965. Dietary chemical composition of cattle and sheep grazing in common on a dry annual range. J. Range Manage. 18:78-85.

Wallace, J.D., J.C. Free, and A.H. Denham. 1972. Seasonal changes in herbage and cattle diets on sandhills grassland. J. Range Manage. 25:100-104. 